\title{
INCLUSIVE EDUCATION IN SCHOOLS: ORGANIZATIONAL-PEDAGOGICAL ASPECTS OF THE PROBLEM
}

\author{
NATALIIA MATVEIEVA
}

\begin{abstract}
The article emphasizes that the urgent need today is to create the necessary conditions for meeting the needs of each child, regardless of its capabilities and other factors in realizing its potential, bringing benefits to society, and feeling that it is a full citizen. The author analyzes the main problems concerning the implementation of inclusive education at the present stage, examines the state of the problem's coverage in scientific works and normative-legal documents. The author focuses on a special place in the process of creating a comfortable environment for teaching children with special needs of psycho-diagnostic tools and correctional programs that need to be adapted. The article emphasizes that compliance with a number of requirements can increase the efficiency of the process of inclusive education in a comprehensive educational institution; outlines the main conditions for improving the quality of provision of educational services for children with special needs.
\end{abstract}

Keywords: inclusive education, adaptation, modification, individual approach, psychological and pedagogical support.

\section{INTRODUCTION}

The XX century is an era of change, including value orientations in educational field, determining the diversity of each individual, due to the transition to humanist "Education for all" As the UNESCOinitiated International movement "Education for all", education occupies a prominent place in the lives of every human being and serves as a priority task to meet the educational needs of each community [7]. At the same time it is urgent to create the necessary conditions to meet the needs and aspirations of every child, regardless of capacity and other factors of realization of their potential, bringing of the benefit to society, with the feeling of being a full citizen. Analysis of experience teaching children with special needs in Europe shows that for the vast majority of them inclusive education is the main form of education of people with disabilities, which promoted and enshrined in a number of regulations, such as: Universal Declaration UN human rights, Declaration of rights of disabled Persons, Convention on the rights of the child, Salamanca, Dakar Declaration and others. Thus, democratic countries promote values of civil society based on the ideas of equality, tolerance, creating of an unlimited space for training, education, development, and so on. This is a particular attention of Convention on the Rights of the Child, which raises requirements to bring the national legislation of each state in line with the "global constitution rights of the child". On the other hand, Salamanca 
Declaration (1994), popular in developed countries, highlights that educational institutions have to take along any and all children regardless of their physical, intellectual, social, emotional, linguistic or other features [4]. In particular the group of people with disabilities, appointed by the above document, include children with mental or physical disabilities and gifted children; unattended children without parents and those who are working; children from remote areas; children belonging to different minority groups; children from disadvantaged or low-income families under 18 and so on. Hence - the term "special needs" is implied for people whose needs depend on the physical or mental state and difficulties in learning and who need educational, medical, social support on the period of studying at the school to improve health, development, training and education, quality of life, participation in public affairs and others.

The analyze of updated source of the problem shows that there are differences in the interpretation of the concept of "inclusive education" which is linked to the specific choice of a particular category of subjects of inclusive education, the originality of goals, objectives and conditions for its implementation. Thus, the problem is seen in different ways by many scientists, N. Artyushenko, V. Bondar, L. Budyak, I. Dmytriyeva, T. Zubaryeva, A. Kolupayeva, S. Mironov, L. Oltarzhevska, T. Sak, V. Synov, M. Semaho, M. Suprun, N. Teplova, S. Fedorenko, A. Chyhryna, A. Shevtsov, M. Sheremet; was the subject of research by L. Vygotsky, D. Harner, A. Dayson, M.-L. Kinh-Sears, M. Kondakov, O. Leontyev, D. Lesko, S. Rubinshteyn, P. Tretyakov, and remains relevant for the future.

Today in Ukraine there is a need for amendments on the practical implementation of inclusive education, based on the law of Ukraine "On Education", "On Preschool Education", "On Protection of Childhood", "On the Rehabilitation of the Disabled in Ukraine", "Concept of Inclusive Education", "Action plan of inclusive education of children requiring correction of physical and (or) mental development in secondary schools for 2009-2012", "Law and "on State program" National Action plan for implementation of the Convention on the Rights of the Child for the period till 2016" (2009), and others. Therefore, in recent years, the government has adopted a large number of regulatory documents that deal with the organization and organization of inclusive education for children with special needs. These are as follows: Resolution of the Cabinet of Ministers of Ukraine dated August 9, 2017 No. 588 "On Amendments to the Procedure for the Organization of Inclusive Education in General Educational Institutions"; Order of the Ministry of Education and Science of Ukraine dated July 21, 2017 No. 1081 "On Approval of the Standard Curriculum for Children with Intellectual Disabilities a moderate and severe degree (elementary school)"; Letter of the Ministry of Education and Science of Ukraine dated July 3, 2017 No. 1 / 9-362 "On the list of educational programs, textbooks and teaching aids, recommended by the Ministry of Education and Science of Ukraine for use in general education their establishments for the education of children with special educational needs (by nosology) in the 2017/2018 academic year"; Letters of the Ministry of Education and Science of Ukraine dated June 14, 2017, No. 1 / 9-325 “On the curricula and the organization of the educational process for students with special educational needs general educational institutions in the 2017/2018 academic year" and the Letter of the Ministry of Education and Science of Ukraine dated February 6, 2017 No. 1/9-63 "On the educational literature for children with special educational needs" etc.

Our research and the State Statistics Service of Ukraine ascertain fact regularly increased in numbers with those people with special needs. For example, the number of children with complex disabilities, covered by the difficulties with studying, and therefore, the group of studyingrehabilitation centers in 2014/2015 was 5.5 thousand. Children (48 centers) In 2015/2016 - 6,4 thousand children (58 establishments). Compared to $2014 / 2015$ in the 2015/2016 academic year, $19 \%$ increase in the number of students in inclusive classrooms (with about $2165-2720$ people), by $36.1 \%$ more than in the previous year were more places of an assistant teacher (994) in schools with inclusive classes. In general, for 5\% (from 4955 to 5265 persons) increased the number of students with special needs enrolled in special schools, for which places are significantly reduced. So, the project "On the organization of inclusive education of children with special educational needs in secondary schools" for ensuring the effectiveness of the educational process class sizes of inclusive education should be 
and no more than 20 pupils, among them, of which 1-3 students with similar disabilities, mental retardation, disorders of the musculoskeletal system, with reduced vision, hearing, mental retardation and others; not more 2 children : blind, hearing impaired, with severe speech disorders; children with complex developmental defects (hearing impairment, vision, musculoskeletal system in conjunction with mental retardation, mental retardation); children on wheelchairs.

However, experience shows that in the implementation of inclusive education in schools there are certain difficulties, related to a number of reasons. On the other hand, inclusive education in Ukraine is largely spontaneous. In particular, much of children with special needs does not receive the necessary educational impact because of the inability of being taken to the school; is the subject of a partial psychological, educational, medical, correctional and rehabilitation accompaniment in learning at school [8, p. 74-76]. Typically, the reason is the partial or complete outfit of the institution to adopt children with special needs, such as: lack of architectural accessibility, appropriate learning environment for the special needs of students (presence of modern correctional and rehabilitation equipment, rates of a remedial teacher and the assistant teacher, extremely insufficient number of adapted buses for the transportation of students with disabilities and, unsatisfactory advisory and educational work on the peculiarities of state educational policy, etc., in particular, not the readiness of general education schools to accept students with special educational needs).

\section{ANALYSIS AND Discussion}

Contextual analysis of the current state of scientific and methodological and logistical support of inclusive education allows to state that for its successful organization school must comply with the requirements, examine and analyze the factors of influencing on the quality of education. This issue is important for researchers and practitioners. Particularly noteworthy researches are by A. Kolupayeva, I. Lyahova, L. Kunenko, A. Shevtsova, D. Shulzhenko that highlight problems and disability, training and education of persons with disabilities mental and physical development; O. Bezpalko, M. Borytk, O. Budnyk, O. Zvyeryeva, A. Kapskoyi, O. Kolesnykova, T. Ostryanko, P. Pavlenko, T. Semyhina, I. Tsushko work on the issue of organizational and educational activities in the social sphere. For instance Z. Romanchak focuses on the isolation of organizational methodical conditions that serve as an atmosphere of cooperation and in an inclusive institution, namely the training and retraining of the teaching staff; provides methodological assistance to teachers in the use of various technologies of inclusive education; learning of aspects of pupils livelihoods; engaging students in various activities (group work) and encourage children with disabilities to participate in training; including parents of students with special needs to the educational process and the cooperation of others. The scientist considers inclusion as favorable basis for providing professional collaboration. The researcher L. Mischyk determines that inclusive school serves as a social and educational system and promoting social inclusion through the creation of a barrier-free environment. Important according to L. Mischyk organization takes psychological and pedagogical support that serves the realization of potential learning opportunities for children with special needs. In general, the effectiveness of inclusive education today depends on a number of conditions.

The meaning of "condition" under the philosophical interpretation is defined as a set of factors influences, creating an environment where something happens. Instead, in terms of psychology condition is a set of phenomena of external and internal environment affecting the development of specific mental phenomena [4, p. 44]. The meaning of the terms in pedagogy defines the condition as "the totality of variables natural, social, external and internal influences acting on the physical, psychological and moral development of man, his behavior, education, formation". In all the above mentioned cases the condition serves as efficiency in achieving the result in practice.

According to the Order of the Ministry of Education and Science of Ukraine of 31.12.2015 № 1436 "On Approval of the Plan of Measures to Ensure the Right to Education for Children with Special Educational Needs in the Educational Sphere", as well as the CMU Decree No. 588 of August 9, 2017 "On Amendments to the Procedure for the Organization of Inclusive Education in general educational 
institutions" and other we find the definition of terms of organization of inclusive education which allows us to determine the difficulties and limitations that may arise in the future education of children with special needs. Specifically the data of normative document would stress that special place in the process of creating a comfortable environment for children with special needs takes psycho - diagnostic instruments and corrective programs that need an adaptation, namely the changing nature of presentation without altering content or a conceptual complexity of the problem and modified according to individual characteristics of the child. This involves the use of these types of adaptation:

1) adaptation of the environment - increasing light intensity in the room (for children with visual impairment), reducing noise in the classroom, the availability of hearing aids (for children with hearing impairment) creating a separate unit in the school premises (for younger students); ensuring physical accessibility (for students in violation of the musculoskeletal system);

2) adaptation of the content, methods and forms of educational activity (change of pace exercises, alternating activities, learning tasks using various levels of complexity, individual approach in determining the time of tasks). Special attention needs to develop learning motivation, the formation of the child's faith in their own abilities as a result of awareness and evaluation of real achievements;

3) adaptation of materials (textbooks, visual and other materials, the use of printed text with different font size etc.).

Thus, in accordance with the Resolution of the Cabinet of Ministers of Ukraine dated July 12, 2017, No. 545 "On Approval of the Regulation on the Inclusion and Resource Center", a decision was made to create these centers whose purpose is to facilitate the organization of the educational process with special children, effective detection and diagnosis children with peculiarities, establishing close relationships with such pupils' families, the public and others.

Letter of the Ministry of Education and Science of Ukraine dated June 14, 2017 No. 1 / 9-325 “On the curricula and organization of the educational process for students with special educational needs of secondary schools in the 2017/2018 academic year" emphasizes the importance of the development of new training plans for arranging quality education of people with special needs. Under such an approach, the creation of comfortable conditions, the adaptation and modification of teaching aids (first of all plans) to the learning of such students becomes of paramount importance. Scientists G. Kravchenko, G. Silina determine that the success of the introduction of inclusive education depends on the awareness of pedagogical workers about the problems arising in the practical activity of the teacher in the process of teaching children with special needs [3]. In particular, scientists highlight the following conditions and ways to overcome the difficulties encountered in working with children with special needs who study in a general education school:

- readiness (psychological, physical and other) to study at school with other children;

- organization and conducting diagnostics of the level of development of a child with special needs;

- creation of all necessary conditions for realization of potential opportunities of such students;

- provision of educational institutions with the required number of highly skilled specialists;

- organization of preparatory work with other students of the school on tolerance and tolerance towards children with special needs;

- creation of special conditions (arrangement of classes for necessary accessories, security mode) [3, p. 16];

- providing students with special needs high-quality psychological and pedagogical, corrective and development support by specialists;

- interaction with the families of pupils with special needs (studying the conditions of residence, the causes of the disease, the pace of development, the personal development trajectory, etc.).

N. Kuzava focuses on the fact that in the process of creating a comfortable environment for inclusive education, upbringing and development of children with special needs should take into account internal and external conditions. Thus, the internal conditions of the scientist consider compliance of mental and physical development of children age norms; the possibility of mastering its comprehensive standard specified amount of knowledge; its psychological readiness for inclusive 
education. Instead, external conditions include early detection of disorders in child development; the desire of parents to teach their children in the secondary school along with other children and the desire to help them in the process of learning and training; providing an effective corrective skilled care; creating an appropriate environment and so on. Generally we can distinguish the following conditions:

1) teaching: the creation of a school necessary conditions for training, education of students with special needs, correctional and developing adapted and inclusive environment, ensuring full inclusion and personal self-realization of such students; creating the conditions for access to education; integration of their parents in the educational environment institutions; Staffing (presence of an assistant teacher, correctional educator and psychologist and, as a speech therapist, a doctor and others); realization of individual and differentiated approaches to learning;

2) organizational - regulatory framework, availability of medical, psychological and educational support that allows the proper level to carry out training and education of children with special needs, serving their adaptation and socialization, work with parents social and educational consultation, individual interviews, etc.; interaction with NGOs, organizing joint activities for children with a standard level of development and their peers with disabilities by involving different activities and forms sports, clubs, exhibitions of works of students, creative competitions, gardening in school, planting in classrooms, etc.;

3) financial and economic conditions and the information providing - a) logistical equipment: architectural accessibility, respect for dignity hygiene and welfare standards, fire and electrical safety, the use of training and rehabilitation and medical supplies, etc.; b) software support of the educational process: the creation of individual educational plan (IHP), availability of appropriate textbooks, electronic educational resources, etc., realization of individual and differentiated ways of learning students with different levels of development and so on.

Important for us is the classification of pedagogical conditions stated by the scientist N. Artyushenko. This includes:

1) adaptive educational environment (overcoming architectural and social barriers, technical and methodological support);

2) accompanied by psychological-pedagogical (individual education of a gram, individual and group correction- developing classes);

3) modified organizational methods and forms of education;

4) raising the professional level of the teacher;

5) the moral and ethical aspect of the problem, which involves the formation of an inclusive culture for all participants of educational process.

On the other hand, the fact that the successful organization of inclusive education of children with special needs in comprehensive schools is impossible without the following:

a) a compilation of conclusions and recommendations for the further development of such students, providing them with high-quality medical-psychological and pedagogical support;

b) systematization of data on the development of children with special needs (compiling a database of children according to their characteristics, an individual card for psychological and pedagogical diagnostics, a diary of observations);

c) drafting an individual program of development (or rehabilitation of children with disabilities);

d) providing the necessary skilled scientific and methodological assistance to inclusive education practitioners; creation of conditions for the implementation of new techniques, forms and methods of working with pupils with special needs, etc.;

e) establishment of psychological and pedagogical support of families with children with special needs (counseling, pedagogical all-rounder, organization of correctional-developmental classes, creation of methodological recommendations and provision of parents, preparation of a social passport of a family by a social pedagogue, etc.).

In particular, pedagogical activities should be oriented towards the interests of the family in which a child with special needs is raised, namely: 
1) recognition of the family as the primary focus of its life, an important factor affecting the stability in the life of the child;

2) systematic and constant exchange with parents of complete and unbiased information regarding children with special needs; understanding of the uniqueness of each family, studying, generalization, respect and further use in the practice of receptions, forms and methods of family education and upbringing;

3) introduction in the educational institution of the policy and system of services that provide families with the necessary psychological and pedagogical (emotional, corrective) and financial support; Encouraging families of pupils with special needs for joint activities on inclusive education;

4) care that the services provided to families are integrated, coordinated, flexible, accessible and in line with the needs of each family; understanding and taking into account the needs, opportunities and interests of children in the development of educational and other programs, an individual program of development, etc.;

5) organization of educational activities among the population in order to prevent and prevent the occurrence of violations in the development of children and further difficulties in the process of their education in general education [8, p. 76].

To the list some national scientists added the need for careful diagnosis of children with disabilities, working closely with the families of the students (parents ensure to voice supported for derivatives advisory (CW), the need to develop methods of training people with disabilities and others. This approach deserves special attention and the need for training of qualified personnel, which could create an appropriate learning environment in schools, prepare students to interact with other children, provide psychological and pedagogical support inclusive education and more. We cannot emphasize that to create a proper inclusive environment is particularly important psychological readiness to school teachers for inclusive education, which requires knowledge of its the philosophical aspect, the main values, aims and objectives, methods and technologies of inclusive practice.

The teacher acts as one of the main figures in the process of introducing inclusive education. As a role model for his colleagues, parents, and the public, the teacher should adapt the training material to the needs of students with special needs; study and observe them in order to prevent their health deterioration, to respond adequately to different manifestations of behavior, to emphasize strengths and abilities; to promote the development of their emotional and personal sphere; use feedback; systematically raise the self-esteem of students with special needs among their peers and their status in the team (create a democratic environment, establish a relationship between children), etc. [1].

The professional, scientific, methodological level of the teacher deserves attention, in particular, deepening of knowledge, formation of abilities and skills of working with such students; studying special medical, psychological and pedagogical literature, acquaintance with modern pedagogical approaches and techniques used in special schools; study of the advanced pedagogical experience not only of teachers of Ukraine, but also of foreign countries. Success of the organization of inclusive education at school depends on the professionalism of the teacher, his desire to work with children, the desire to create a comfortable inclusive environment [6]. On the other hand, another important aspect is the personal one, in particular individual qualities and features, such as: mercy, respect, kindness, mutual understanding, self-sacrifice, nobility, tolerance, patience, optimism, faith in oneself, and others.

Only in such circumstances, the process of enrolling in a general education school will be painless for children with special needs, will allow them to assert themselves and believe in their own strengths and opportunities, and will encourage further growth.

"Particularly important today is the formation of positive public opinion on tolerance towards people with special needs and advocate the nature and content of inclusive education among parents. It is reasonable to involve mass-media and volunteer organizations that will facilitate a successful integration and education of persons with disabilities in institutions of different types: kindergartens, comprehensive schools, vocational schools, higher educational institutions, postgraduate education establishments" [2, p. 104]. 
However, the main condition for establishing cooperation with disciples with special needs is teamwork, which is characterized as:

- joint work of all specialists of the educational institution, parents and the public on decisionmaking and equal responsibility;

- inclusion of parents of pupils with special needs prior to the adoption of a personal trajectory for the development of children;

- use of the achievements of theory and practice, experience of European countries, innovative teachers, educational institutions in the practical work of each teacher, etc.

\section{CONCLUSIONS}

Today scientists actualize the need to create a model of implementation of inclusive education in all Ukrainian schools, development of methods for determining and providing additional services to children with disabilities, training teaching staff, cooperation with the families of these students, development of a data bank on training, education and development of children with special needs, etc. That will practically implement quality inclusive teaching.

"Effective implementation of inclusive education in Ukraine is possible with the combination of certain factors: sufficient school funding, improvement of regulatory and legal base, developing teaching methods, tools of inclusive education, training teachers for realizing inclusive education in their teaching practice" [2, p. 104]. From the above definitions we can conclude that the quality of educational services for children with special needs depends on many factors. Particularly noteworthy we consider organizational, educational, economic conditions, without which it is impossible to create a proper inclusive environment with a free-barrier space for training, education and development of all children without exception.

\section{REFERENCES}

[1] Budnyk O. Inclusive education. Publisher Boichuk A.B., Ivano-Frankivsk, 2015. (in Ukrainian)

[2] Dubkovetska I., Budnyk O., Sydoriv S. Implementing inclusive education in Ukraine: problems and perspectives. Journal of Vasyl Stefanyk Precarpathian National University. Scientific Edition: Series of Social and Human Sciences, 3 (2-3) (2016), 99-105. doi:10.15330/jpnu.3.2-3.99-105

[3] Kravchenko G., Silina G. Inclusive education. “Morning”, Kharkiv, 2014. (in Ukrainian)

[4] Psychological encyclopedia. Akademvydav, Kyiv, 2006. (in Ukrainian)

[5] Salamanca Declarations. Frames for action on education for persons with special needs, adopted by the World Conference on Special Needs Education. Salamanca, 7-10 July, 1994. (in Spanish)

[6] Turishcheva L. Children with peculiarities of development in ordinary school. Group "Osnova", Kharkiv, 2011. (in Ukrainian)

[7] UNESCO (United Nations Educational Scientific and Cultural Organization) in 1999. Statistical Yearbook, Paris, 1999. (in French)

[8] Voloshin O. Work with Children with Special Educational Needs. Psychologist, 8 (2015), 559-560. (in Ukrainian)

Address: Nataliia Matveieva, Vasyl Stefanyk Precarpathian National University, 57, Shevchenko Str., IvanoFrankivsk, 76018, Ukraine.

E-mail: nataliematveieva@gmail.com.

Received: 14.12.2017; revised: 02.03.2018. 
Матвеєва Наталія. Інклюзивне навчання в школі: організаційно-педагогічний аспект проблеми. Журнал Прикарпатського університету імені Василя Стефаника, 5 (1) (2018), 80-87.

У статті обгрунтовано актуальність проблеми створення необхідних умов для задоволення потреб кожної дитини, незалежно від їі мождивостей та інших чинників щодо реалізації свого потенціалу, принесення користі суспільству, відчуття себе їі повноправним громадянином. Здійснено аналіз основних проблем щодо реалізації інклюзивної освіти на сучасному етапі, досліджуе стан висвітлення проблеми у наукових працях та нормативно-правових документах. Акцентовано увагу на особливому місці у процесі створення комфортного середовища для навчання дітей з особливими потребами психодіагностичного інструментарію та корекційних програм, які потребують адаптації. Наголошено на тому, що дотримання низки вимог дозволяє підвищити ефективність процесу впровадження інклюзивного навчання у загальноосвітній навчальний заклад; виокремлено основні умови, що слугують підвищенню якості надання освітніх послуг дітям з особливими потребами.

Ключові слова: інклюзивна освіта, інклюзивне навчання, адаптація, модифікація, індивідуальний підхід, психолого-педагогічний супровід. 